\title{
Dynamic Angular Petrissage as Treatment for Axillary Web Syndrome Occurring after Surgery for Breast Cancer: a Case Report
}

\author{
Paul A. Lewis, BA, RMT, CDT, ${ }^{1 *}$ and Joan E. Cunningham, $\mathrm{PhD}^{2}$ \\ ${ }^{1}$ Paul Alexander Lewis Services, Inc., Mississauga, ON, Canada; \\ ${ }^{2}$ Cancer Epidemiologist and Independent Scholar, National Coalition of Independent Scholars, San Antonio, TX, USA
}

Background: In the context of breast cancer, axillary web syndrome (AWS), also called lymphatic cording, typically presents in the weeks after axillary surgery. This painful condition, likely lymphofibrotic in origin, restricts upper extremity range of motion (ROM). There is no established treatment, although physical therapy and other approaches have been used to variable effect. This report describes treatment of a female client with AWS, who had recently undergone a unilateral simple mastectomy with sentinel node biopsy plus axillary dissection.

Methods: The client presented with pain upon movement (self-reported as 5 on the $0-10$ Oxford Pain Scale), visible cording and restricted use of the ipsilateral upper extremity. Clinical assessment included determining the extent of AWS cording (taut, from axilla to wrist) and measuring glenohumeral joint $\mathrm{ROM}\left(\mathbf{1 4 0}^{\circ}\right.$ flexion by goniometer $)$. A therapeutic massage with movement protocol, termed dynamic angular petrissage, was administered over two sessions: Swedish massage combined with dynamically taking the limb through all possible angles of movement (passive ROM), controlling stretch and tension while simultaneously and segmentally applying petrissage and non-petrissage techniques to the underlying soft tissue. Careful attention was taken to not break the cord. Home care consisted of prescribed exercises performed by the patient.

Results: After Session One, pain was reduced (to 0/10), ROM improved (to $170^{\circ}$ flexion), and cording was visibly reduced. After Session Two the cord was residually apparent only on hyperextension, with no ROM restrictions in glenohumeral joint flexion. Follow-up at three months revealed absence of visual or palpable evidence of cording, unrestricted glenohumeral joint ROM, and absence of movement-associated pain.

Conclusion: The signs and symptoms of AWS were quickly and effectively eliminated, without causing any pain or discomfort to the client. We propose that dynamic angular petrissage may be an efficient and safe treatment approach for reducing the pain, mobility restrictions, and cording of AWS.
KEY WORDS: axillary web syndrome; Mondor's disease; sclerosing venous thrombophlebitis; massage therapy; axillary surgery

\section{INTRODUCTION}

Surgery to the axilla for breast cancer staging and/or regional disease control is associated with risks of pain, stiffness, and diminished shoulder, arm and chest mobility. ${ }^{(1-5)}$ In addition, many patients develop axillary cording/webbing, also called axillary web syndrome (AWS) or lymphatic cording. ${ }^{(6-8)}$ AWS typically presents in the weeks or months after surgery as one or more tightened, externally visible and palpable rope-like structures. It typically develops under the skin of the inner arm, starting near the site of axillary surgical trauma and extending across the medial aspect of the arm to the antecubital fossa of the elbow, sometimes into the wrist and thumb; ${ }^{(7-10)}$ cords may also be seen on the chest wall caudal to the axilla. ${ }^{(11)}$ Cord(s) may be clearly visible and palpable, or evidenced as pain and tightness upon raising the arm to and above shoulder level. Earlier reports called this "Mondor's disease", attributed to superficial sclerosing venous thrombophlebitis. ${ }^{(12-13)}$ Pathophysiology is now thought to be angiolymphatic and fibrotic in origin, with lymphatic and fibroblastic involvement, and the cord may be exacerbated by tightness of surrounding tissue. ${ }^{(5-8,10,13-17)}$

AWS is more common than generally appreciated, with reported prevalence as high as $85 \%$ of women receiving axillary surgery for breast cancer. ${ }^{(5-8,10,14-15,18-20)}$ Risk factors may include younger age, lower body mass index, mastectomy, and greater numbers of lymph nodes removed. ${ }^{(8)}$ Risk appears to be greater with either Levels I-II axillary dissection or axillary clearance (Level III dissection) than with sentinel lymph node biopsy alone, although not all investigators agree. $(21,22)$ AWS is considered by some to be self-limiting, with spontaneous resolution after some weeks or many months, but this is not universally accepted and the experience of physical therapists suggests that 
pain and disability of untreated AWS may persist for years. ${ }^{(5,8,11,19,23-26)}$

No standard of care has been established for the prevention or treatment of AWS. Manual therapies including myofascial release, scar massage, and lymphatic drainage techniques, as well as physical therapy, thermal therapy, surgery, and oral agents (anti-inflammatories and antibiotics ${ }^{(26)}$ ) have been reviewed in detail by Yeung et al. ${ }^{(8)}$ Manual methods and physical therapy usually involve conservative treatment in several sessions over weeks or even months, with varying degrees of success in symptom reduction and cord resolution. ${ }^{(8,15,18-19,23-25,27)}$ Manual axial distraction with firm digital pressure applied at various points to rupture the cord (usually at the first session) successfully relieved pain and movement limitations in a series of patients, ${ }^{(12)}$ but, as with most prospective studies and case reports, any negative consequences for healing and particularly for risk of lymphedema were not investigated. ${ }^{(8)}$

This retrospective case report describes the use of specific therapeutic massage techniques, including Swedish massage with passive ROM, to relieve signs and symptoms of AWS over two treatment sessions in a young woman who had recently undergone mastectomy and axillary surgery for breast cancer. The goal was to improve upper extremity movement associated with pain and restricted mobility in areas affected by AWS. This report follows the CARE (Consensusbased Clinical Case Reporting) guidelines for case reports $^{(28)}$ as adapted for therapeutic massage and bodywork. ${ }^{(29)}$

\section{METHODS}

\section{Case Presentation}

Management of this case consisted of two treatment visits (1.5 and 1.0 hour, respectively) within a five-day period, and a third non-treatment visit approximately 14 weeks later.

\section{Client information}

The client was a 45-year-old Caucasian woman residing in Toronto, Canada. At presentation with AWS, she had pain associated with movement of the upper left extremity and visually evident cording from axilla to wrist. Table 1 presents a timeline of pertinent events. Briefly, she had undergone left breast lumpectomy for breast cancer, followed five weeks later by simple mastectomy with axillary surgery (sentinel node biopsy plus axillary dissection), including removal of several lymph nodes and axillary contents containing breast tissue, underlying fascia and skeletal muscle. She did not receive chemotherapy or radiotherapy. According to the client, during the first three weeks post-mastectomy she had received basic post-surgery rehabilitative physical therapy and was instructed in standard range of motion (ROM) exercises. When this did not resolve the continuing post-surgical, movement-associated pain and diminished ROM, she sought a single massage treatment (from the first author), with considerable improvement in both pain and ROM. Neither client nor therapist detected any cording at this visit.

About 4.5 weeks post-mastectomy, the client first observed cording involving the ipsilateral axilla and also the entire length of the arm. The cording was associated with new pain and discomfort and restricted use of the entire limb. Two weeks later, at 6.5 weeks post-mastectomy (and after consulting her surgeon), she sought massage treatment from the first author for this new condition, stating that her surgeon acknowledged the cording but could not offer any treatment suggestions.

\section{Presentation (6.5 weeks after mastectomy)}

The client presented with restricted use of the left upper extremity, pain upon movement and visible cording (Figure 1(a)). She described "pain, tightness, a 'tugging' under the skin and a visible ropey tightness .... This 'rope' extends all the way down my arm, especially with pain at the elbow and again at the inner wrist. When I press anywhere on this pathway down the arm, there's a stinging tight pain.... [The rope] originates near a bubble of stitched skin at my axilla". She expressed reservations towards selfpalpation of numb areas associated with the surgical scar because of unpleasant, wooden sensations, but also stated her willingness to allow treatment including these areas.

TABLE 1. Timeline of Events

\begin{tabular}{|c|c|c|}
\hline $\begin{array}{l}\text { Time from } \\
\text { Mastectomy } \\
\text { (weeks) }\end{array}$ & $\begin{array}{l}\text { Time from } \\
\text { Session One } \\
\text { (weeks) }\end{array}$ & Event \\
\hline-5 & & Lumpectomy (left breast) \\
\hline 0 & & $\begin{array}{l}\text { Simple mastectomy with axillary } \\
\text { surgery (sentinel node biopsy plus } \\
\text { axillary dissection) }\end{array}$ \\
\hline $0-3$ & & Basic rehabilitative physical therapy \\
\hline 4 & & $\begin{array}{l}\text { Persisting pain and restricted ROM, } \\
\text { sought treatment from first author }\end{array}$ \\
\hline 4.5 & & $\begin{array}{l}\text { Patient notices cording, involving } \\
\text { axilla and arm }\end{array}$ \\
\hline 5.5 & & $\begin{array}{l}\text { Patient consults surgeon (no treatment } \\
\text { offered) }\end{array}$ \\
\hline 6.5 & 0 & $\begin{array}{l}\text { Treatment Session One using dynamic } \\
\text { angular petrissage }\end{array}$ \\
\hline 7 & 0.5 & $\begin{array}{l}\text { Treatment Session Two using dynamic } \\
\text { angular petrissage }\end{array}$ \\
\hline 15 & 8.5 & $\begin{array}{l}\text { Patient reports progress and provides } \\
\text { photo (unsolicited) }\end{array}$ \\
\hline 21 & 14.5 & Follow-up (non-treatment) visit \\
\hline
\end{tabular}



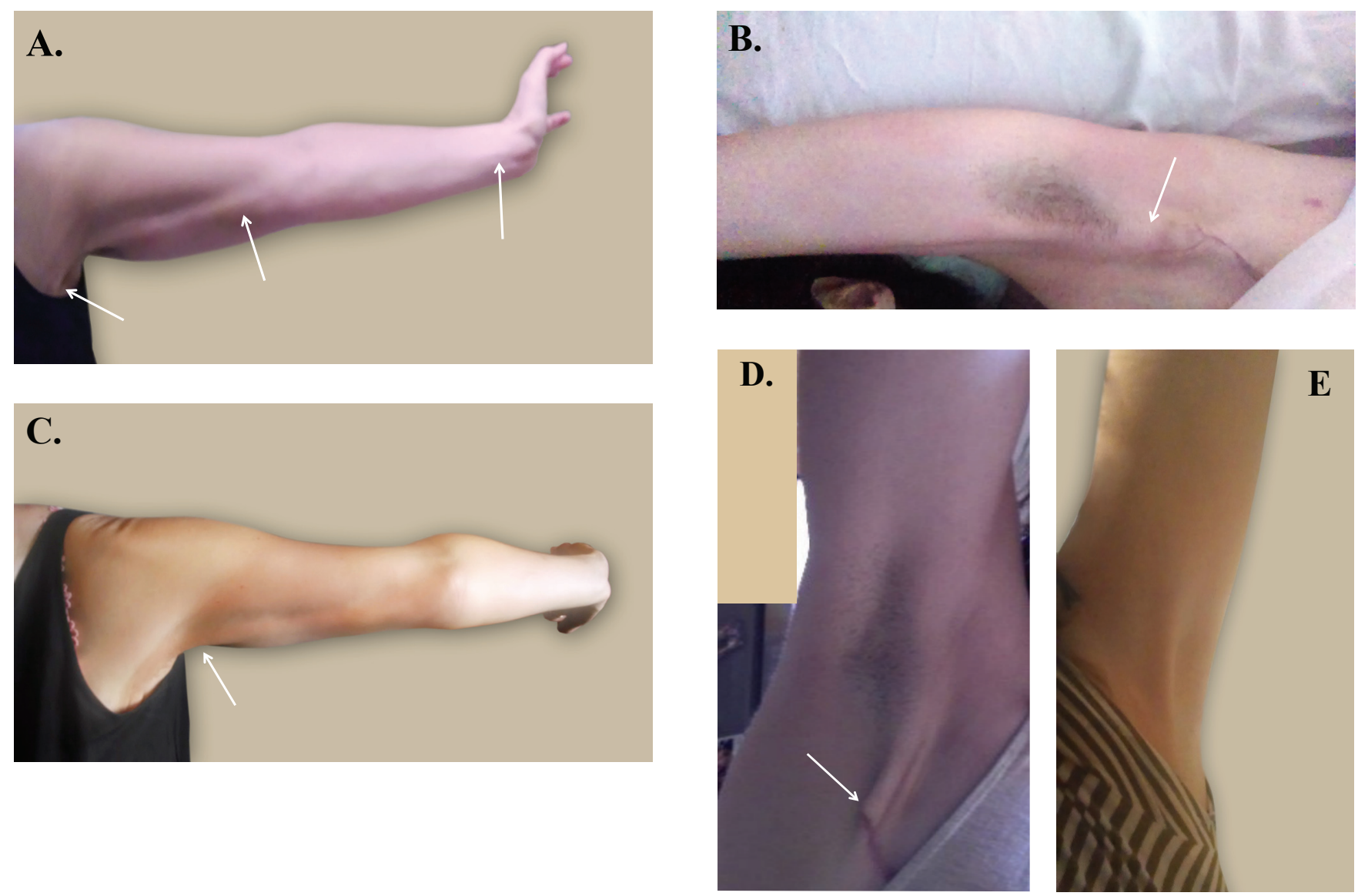

FIGURE 1. Cording before and after treatment with dynamic angular petrissage. (a) Before first treatment: cording (arrows) is clearly seen from axilla to elbow and wrist; (b) immediately after first treatment: cording prominence (arrow) is reduced and range of motion increased; (c) before second treatment: cording (arrow) is visible only on hyperextension; (d) eight weeks after second treatment: cording is localized to vicinity of the surgical scar (arrow), seen on full extension (photo provided by patient, taken using a mirror); e) 14 weeks after second treatment: cording is no longer visible, even on extension.

\section{Assessment measures}

Baseline condition and treatment outcomes (Table 2) were assessed by: visual inspection of client posture; active-free ROM testing, that is, observing movement as performed by the client unaided by the therapist; passive-relaxed ROM testing, that is, as performed by therapist unaided by the client; extent of glenohumeral $(\mathrm{GH})$ flexion as measured with goniometer with normal being $180^{\circ}$;(30) client self-rated movement-associated pain, reported upon request using the 0 to 10 "Oxford Scale" where 0 is no pain and 10 is severe pain; ${ }^{(30)}$ visual inspection of cording; palpation of cording for extent, tautness, and texture; visual inspection and palpation for evidence of lymphedema; and client query of lymphedema signs and symptoms.

\section{Assessment}

Methods of assessment are described in Table 2. Locations from which pain and restrictions originated were identified. On standing, the client was observed to have slight anterior rotation of the left shoulder. Bilateral active-free functional testing and palpation of upper extremities including neck and shoulder revealed high resting tension of the left levator scapula restricting cervical movement to the right, and restricted ROM of the GH joint in abduction and during flexion (maximum $140^{\circ}$ flexion). Pain on movement was self-rated by the client as 5/10. Active-free ROM testing of elbow and wrist revealed restricted extension of these joints, with self-rated pain levels $4 / 10$ and $2 / 10$, respectively. She stated the restrictions and pain were due to the cording, which was clearly evident in abduction as a rope-like structure from axilla to antecubital fossa of the elbow, and as a finer dental floss-like structure from elbow to the radial side of wrist (Figure 1(a)). Visual inspection and palpation of shoulder and arm revealed no evidence of lymphedema; lymphedema signs and symptoms were denied by the client.

\section{Outcomes desired by client}

These were to regain freedom of movement of shoulder, elbow, and wrist, to eliminate 
TABLE 2. Summary of Assessments of Left Upper Extremity

\begin{tabular}{|c|c|c|c|c|c|c|c|}
\hline \multirow[t]{2}{*}{ Assessment } & \multirow[t]{2}{*}{ Site } & \multicolumn{2}{|c|}{ Treatment Session One (Week 0) } & \multicolumn{2}{|c|}{ Treatment Session Two (Week 0.5) } & \multirow{2}{*}{$\begin{array}{c}\text { Phone } \\
\text { Call } \\
\text { (Week 8.5) }\end{array}$} & \multirow{2}{*}{$\begin{array}{c}\text { Follow-Up Visit } \\
\text { (Week 14.5) }\end{array}$} \\
\hline & & Pre (Baseline) & Post & Pre & Post & & \\
\hline $\begin{array}{l}\text { Stance and Posture } \\
\text { (visual inspection) }\end{array}$ & Shoulder & $\begin{array}{l}\text { Slight anterior } \\
\text { rotation }\end{array}$ & $\begin{array}{l}\text { No apparent } \\
\text { anterior rotation }\end{array}$ & $\begin{array}{l}\text { No apparent } \\
\text { anterior rotation }\end{array}$ & $\begin{array}{l}\text { No apparent } \\
\text { anterior } \\
\text { rotation }\end{array}$ & -- & $\begin{array}{l}\text { No apparent } \\
\text { anterior rotation }\end{array}$ \\
\hline \multirow{3}{*}{$\begin{array}{l}\text { Active-free ROM } \\
\text { functional testing } \\
\text { (movement } \\
\text { performed } \\
\text { by client) }\end{array}$} & Cervical & $\begin{array}{l}\text { Restricted } \\
\text { abduction and } \\
\text { rotation to left }\end{array}$ & No restrictions & No restrictions & No restrictions & -- & No restrictions \\
\hline & GH joint & $\begin{array}{l}\text { Restricted } \\
\text { flexion and } \\
\text { abduction }\end{array}$ & $\begin{array}{l}\text { Somewhat } \\
\text { restricted flexion } \\
\text { and abduction }\end{array}$ & $\begin{array}{l}\text { Full flexion and } \\
\text { abduction, no } \\
\text { restrictions }\end{array}$ & $\begin{array}{l}\text { Full flexion } \\
\text { and abduction, } \\
\text { no restrictions }\end{array}$ & -- & $\begin{array}{l}\text { Full flexion and } \\
\text { abduction, no } \\
\text { restrictions }\end{array}$ \\
\hline & $\begin{array}{l}\text { Elbow } \\
\text { and wrist }\end{array}$ & $\begin{array}{l}\text { Restricted } \\
\text { extension }\end{array}$ & $\begin{array}{l}\text { Somewhat } \\
\text { restricted } \\
\text { extension }\end{array}$ & $\begin{array}{l}\text { Full extension; } \\
\text { Some restriction } \\
\text { on hyperextension }\end{array}$ & $\begin{array}{l}\text { Full extension, } \\
\text { even on } \\
\text { hyperextension. }\end{array}$ & -- & $\begin{array}{l}\text { Full extension, } \\
\text { even on } \\
\text { hyperextension }\end{array}$ \\
\hline \multirow[t]{2}{*}{$\begin{array}{l}\text { Passive-relaxed } \\
\text { ROM testing } \\
\text { (movement } \\
\text { performed by } \\
\text { therapist) }\end{array}$} & GH joint & $\begin{array}{l}\text { High resting } \\
\text { tension of } \\
\text { levator scapula, } \\
\text { restricted ROM } \\
\text { on abduction and } \\
\text { flexion }\end{array}$ & -- & -- & -- & -- & -- \\
\hline & $\begin{array}{l}\text { Elbow } \\
\text { and wrist }\end{array}$ & $\begin{array}{l}\text { Springy end-feel, } \\
\text { restricted ROM }\end{array}$ & $\begin{array}{l}\text { Normal end-feel, } \\
\text { no restrictions }\end{array}$ & $\begin{array}{l}\text { Normal end-feel, } \\
\text { no restrictions }\end{array}$ & $\begin{array}{l}\text { Normal } \\
\text { end-feel, no } \\
\text { restrictions }\end{array}$ & -- & $\begin{array}{l}\text { Normal } \\
\text { end-feel, no } \\
\text { restrictions }\end{array}$ \\
\hline \multirow{3}{*}{$\begin{array}{l}\text { Movement- } \\
\text { associated pain } \\
\text { (self-rated, using } \\
\text { Oxford Scale) }\end{array}$} & GH joint & $5 / 10$ & $0 / 10$ & $0 / 10$ & $0 / 10$ & $0 / 10$ & $0 / 10$ \\
\hline & Elbow & $4 / 10$ & $0 / 10$ & $0 / 10$ & $0 / 10$ & $0 / 10$ & $0 / 10$ \\
\hline & Wrist & $2 / 10$ & $0 / 10$ & $0 / 10$ & $0 / 10$ & $0 / 10$ & $0 / 10$ \\
\hline $\begin{array}{l}\text { GH flexion } \\
\text { (goniometer) }\end{array}$ & GH joint & $140^{\circ} / 180^{\circ}$ & $170^{\circ} / 180^{\circ}$ & $\begin{array}{l}\text { Not measured, as } \\
\text { per Active-free } \\
\text { results }\end{array}$ & $\begin{array}{l}\text { Not measured, } \\
\text { as per Active- } \\
\text { free results }\end{array}$ & -- & $\begin{array}{l}\text { Not measured, } \\
\text { as per Active- } \\
\text { free results }\end{array}$ \\
\hline \multirow[t]{2}{*}{$\begin{array}{l}\text { Cording (visual } \\
\text { inspection) }\end{array}$} & $\begin{array}{l}\text { UOQ } \\
\text { to AF }\end{array}$ & Prominent & Less prominent & Minimal & $\begin{array}{l}\text { Residual in } \\
\text { axilla only }\end{array}$ & $\begin{array}{l}\text { Axillary } \\
\text { scar area } \\
\text { (Fig. 1D) }\end{array}$ & None \\
\hline & $\begin{array}{l}\text { Elbow } \\
\text { to wrist }\end{array}$ & Prominent & Less prominent & None & None & None & None \\
\hline \multirow[t]{2}{*}{ Cording (palpation) } & $\begin{array}{l}\mathrm{UOQ} \\
\text { to } \mathrm{AF}\end{array}$ & $\begin{array}{l}\text { Prominent, taut, } \\
\text { rope-like }\end{array}$ & Diminished & Minimal & Residual only & -- & None \\
\hline & $\begin{array}{l}\text { Elbow } \\
\text { to wrist }\end{array}$ & $\begin{array}{l}\text { Prominent, taut, } \\
\text { floss-like }\end{array}$ & Diminished & $\begin{array}{l}\text { Minimal, only on } \\
\text { hyperextension }\end{array}$ & Residual only & -- & None \\
\hline $\begin{array}{l}\text { Lymphedema } \\
\text { (visual inspection, } \\
\text { palpation, self- } \\
\text { report) }\end{array}$ & $\begin{array}{l}\text { Upper } \\
\text { extremity }\end{array}$ & None & None & None & None & -- & None \\
\hline
\end{tabular}

$\mathrm{AF}=$ antecubital fossa $\mathrm{GH}=$ glenohumeral; $\mathrm{ROM}=$ range of motion; $\mathrm{UOQ}=$ area of chest wall where breast upper outer quadrant had been prior to mastectomy (see arrow, Figure 1(a)).

movement-associated pain, and to reduce prominence of the cord visibly, as well as functionally, so it would no longer interfere with normal activities and self-care including underarm shaving.
Informed consent

The client consented to the treatment plan and to non-identifying photography of the affected area before and after treatment. She provided written consent 
for her clinical information, photos (including one photo provided by the client), treatment, outcomes, and candid comments to be included in this report.

\section{Therapeutic Intervention}

\section{Provider}

All treatment was provided by the first author, a Registered Massage Therapist in private practice in Canada, with six years of clinical experience at the time of this case. He is registered in Canada with the College of Massage Therapists of Ontario (CMTO), in the US with the American Massage Therapy Association (AMTA), and in Great Britain with the Federation of Holistic Therapies (FHT). A graduate of the Sutherland-Chan School and Teaching Clinic in Toronto, Canada, his experience includes ambulatory care clinics; spinal cord rehabilitation; high-risk pregnancy and post-partum; management of breast implants, TRAM reconstruction, lumpectomy, mastectomy, and post-radiation massage; lymphatic movement and drainage; combined decongestion therapy, and sports massage and reflexology.

\section{Techniques used}

Recently, a therapeutic treatment approach combining massage with passive movement has been developed by the first author specifically for treatment of soft tissue problems including restricted ROM as seen in AWS. Termed dynamic angular petrissage, it builds on established methods of Swedish massage, petrissage and non-petrissage techniques, ${ }^{(31)}$ and incorporates passive-relaxed movement. The innovative addition is the dynamic and angular segmental use of petrissage techniques, such as light muscle stripping, and non-petrissage techniques, such as stretching and myofascial release, to reduce restrictions from proximal to distal. Upon identifying the lesion, the therapist engages the proximal aspect using thumb and fingertip pressure, engaging the barrier. Digital pressure is maintained at the barrier while simultaneously lengthening the tissue using the distal limb in a passive, eccentric manner. The technique is dynamically adjusted to address the lesion three-dimensionally as it releases, all the while remaining within the client's ROM and comfort zone. That is, while using one hand to gently knead (petrissage) the soft tissue, simultaneously the other hand is used to passively increase (lengthen) and decrease (shorten) tension on the target tissue via changes in limb position and angle (i.e., with the limb serving as a lever). Utilizing the muscle's line of pull and attachment - changing the lever angles - mimics the natural movement of the muscle. Petrissage and non-petrissage techniques are applied segmentally along the length of the target tissue, as it is stretched and relaxed. This combination gradually and segmentally stretches the target tissues, with minimal risk of engaging the stretch reflex (protective contraction). Should the client experience discomfort at a specific angle or position, the applied pressure or stretch is reduced; the same target area may be addressed from a different angle. The pressure applied and techniques selected are adapted according to the desired local outcome and differences in muscle tone, texture, and underlying structures along the length of the treatment area. The therapeutic purposes of this treatment method are to reduce soft tissue restrictions that compromise movement and generate associated pain while remaining within the client's ROM and comfort zone, and to reduce the time spent in rehabilitation and speed recovery.

In the context of this client with AWS, the specific objective was to reduce the pull of the cord on musculature, adhesions, and underlying structures from axilla to wrist and thereby reduce the tension of involved tissues and restrictions on ROM. Treatment was designed to avoid tearing the cord, which might initiate a local inflammatory process and conceivably increase risk for lymphedema, particularly if the cord is indeed primarily lymphatic and relevant to lymphatic drainage of the arm. The client was initially treated within her restricted ROM to minimize any treatment discomfort. Long petrissage strokes and/or short segmental strokes were used in the dynamic and angular manner described to gradually and segmentally lengthen the target tissue, allowing movement of the joints beyond the presenting limitations.

\section{Session One (1.5 hours)}

Table 3 outlines the treatment components and their approximate duration. Following completion of clinical assessment (10 $\mathrm{min})$, with the client in a supine position integrative lymph drainage techniques were applied to neck and shoulder areas with preventive intent $(5 \mathrm{~min})$. All accessible structures that may have directly or indirectly contributed to the client's condition were then addressed. In particular, interrelationships between clavicle, GH and scapulothoracic joint are critical in helping with full functional ROM. ${ }^{(32)}$ Therefore, light effleurage strokes were applied to neck, shoulder, and pectoral regions to warm and prepare the tissues. The scapula was mobilized along with gentle oscillations to the sternoclavicular joint and acromioclavicular joint with the purpose of structurally assisting scapulothoracic movement; similarly, to assist with GH joint ROM, gentle traction was applied (to slightly loosen the joint and decompresses the articular surface) prior to posterior glide mobilization (to assist with ease of movement of the GH joint during flexion) and then long axis traction (to assist with abduction). Oscillations, traction with posterior glide mobilization, and long axis traction were all applied at Grade 1 levels (i.e., gently) utilizing available joint play to loosen the capsule without stretching any tissues beyond existing laxity. ${ }^{(33)}$ Treatment using methods of dynamic angular petrissage was applied to the ipsilateral pectorals, deltoids and sub-scapularis, 


\begin{tabular}{|c|c|c|c|c|}
\hline \multirow[b]{2}{*}{ Technique } & \multirow[b]{2}{*}{ Structures/Areas Addressed } & \multirow{2}{*}{$\begin{array}{c}\text { Lever Used } \\
(D A P)\end{array}$} & \multicolumn{2}{|c|}{ Treatment Session ${ }^{a}$} \\
\hline & & & $\begin{array}{c}\text { One } \\
(90 \mathrm{~min})\end{array}$ & $\begin{array}{c}\text { Two } \\
(60 \mathrm{~min})\end{array}$ \\
\hline Clinical Assessment & Cervical (neck), shoulder, elbow, wrist & -- & $10 \mathrm{~min}$ & $5 \min$ \\
\hline Integrative Lymph Drainage & Head/cervical/shoulder area & -- & $5 \mathrm{~min}$ & $5 \mathrm{~min}$ \\
\hline Effleurage & Cervical area, shoulder, pectoralis major, deltoids & -- & $3 \mathrm{~min}$ & $1-2 \mathrm{~min}$ \\
\hline \multicolumn{5}{|l|}{ DAP with: } \\
\hline - gentle adaptive petrissage with muscle stripping & $\begin{array}{l}\text { Cervical including SCM, scalenes, upper } \\
\text { trapezius, occipital, and anterior neck muscles }\end{array}$ & Head & $5 \mathrm{~min}$ & $5 \min$ \\
\hline - gentle adaptive petrissage with muscle stripping & Deltoids & Humerus & $5 \mathrm{~min}$ & $3 \mathrm{~min}$ \\
\hline Effleurage & Biceps, triceps, shoulder girdle & -- & $1 \mathrm{~min}$ & $1 \mathrm{~min}$ \\
\hline \multicolumn{5}{|l|}{ DAP with: } \\
\hline $\begin{array}{l}\text { - gentle adaptive petrissage with segmental } \\
\text { muscle stripping }\end{array}$ & Biceps, brachialis, triceps & $\begin{array}{l}\text { Radius } \\
\text { and ulna }\end{array}$ & $5 \min$ & $2 \min$ \\
\hline $\begin{array}{l}\text { - gentle adaptive petrissage with segmental } \\
\text { muscle stripping }\end{array}$ & $\begin{array}{l}\text { Pectoralis major: clavicular and sternal portions, } \\
\text { including mastectomy area }\end{array}$ & Humerus & $5 \mathrm{~min}$ & $1 \mathrm{~min}$ \\
\hline • effleurage & Subscapularis, axilla, lateral border of scapula & Humerus & $1 \mathrm{~min}$ & $30 \mathrm{sec}$ \\
\hline - joint mobilization & Acromioclavicular, sternoclavicular & Humerus & $1 \mathrm{~min}$ & $1 \mathrm{~min}$ \\
\hline $\begin{array}{l}\text { - joint mobilization: posterior glide, long axis } \\
\text { traction }\end{array}$ & GH joint & Humerus & $2 \mathrm{~min}$ & $2 \mathrm{~min}$ \\
\hline • joint mobilization & Scapula & $\begin{array}{l}\text { Scapula, } \\
\text { humerus }\end{array}$ & $1 \mathrm{~min}$ & $1 \mathrm{~min}$ \\
\hline - gentle adaptive petrissage with muscle stripping & Subscapularis, triceps & Humerus & $3 \mathrm{~min}$ & $1 \mathrm{~min}$ \\
\hline $\begin{array}{l}\text { - gentle adaptive petrissage with segmental } \\
\text { muscle stripping }\end{array}$ & Cording from axilla to distal biceps & Humerus & $10 \mathrm{~min}$ & $1 \mathrm{~min}$ \\
\hline - gentle adaptive dynamic myofascial release & Cording of medial biceps & Humerus & $5 \mathrm{~min}$ & -- \\
\hline - effleurage & Forearm extensors and flexors & Radius and ulna & $1 \mathrm{~min}$ & $30 \mathrm{sec}$ \\
\hline - gentle adaptive petrissage with muscle stripping & $\begin{array}{l}\text { Cubital fossa, distal biceps, proximal extensors } \\
\text { and flexors }\end{array}$ & Radius and ulna & $4 \mathrm{~min}$ & $1 \mathrm{~min}$ \\
\hline - gentle adaptive dynamic myofascial release & $\begin{array}{l}\text { Cubital fossa, distal biceps, proximal extensors } \\
\text { and flexors }\end{array}$ & Radius and ulna & $2 \min$ & -- \\
\hline - gentle adaptive muscle stripping & Forearm extensors and flexors, brachioradialis & Radius and ulna & $5 \mathrm{~min}$ & $1 \mathrm{~min}$ \\
\hline - gentle adaptive dynamic myofascial release & Cording of medial forearm & Hand & $3 \min$ & $1 \mathrm{~min}$ \\
\hline - gentle adaptive petrissage with muscle stripping & Cording of distal medial forearm & Hand & $3 \mathrm{~min}$ & $1 \mathrm{~min}$ \\
\hline - gentle adaptive dynamic myofascial release & Cording of distal medial forearm & Hand & $2 \mathrm{~min}$ & -- \\
\hline - effleurage & From hand to shoulder & $\begin{array}{l}\text { Hand, radius } \\
\text { and ulna, } \\
\text { humerus }\end{array}$ & $2 \min$ & $30 \mathrm{sec}$ \\
\hline \multicolumn{5}{|l|}{$\begin{array}{l}\text { Self-care exercises ("L" circles; elbow and wrist } \\
\text { extension): }\end{array}$} \\
\hline • demonstration by therapist & Shoulder girdle, elbow and wrist & -- & $2 \mathrm{~min}$ & -- \\
\hline - client practice & Shoulder girdle, elbow and wrist & -- & $4 \mathrm{~min}$ & -- \\
\hline Various techniques & Areas other than upper extremity & -- & -- & $25 \mathrm{~min}$ \\
\hline
\end{tabular}

${ }^{a}$ Minutes for each treatment component are approximate.

$\mathrm{DAP}=$ dynamic angular petrissage $\mathrm{GH}=$ glenohumeral joint; $\mathrm{SCM}=$ sternocleidomastoid.

bilateral cervical and upper trapezius, and ipsilateral biceps, triceps, forearm extensors, and forearm flexors. The soft tissue manipulations were applied within the client's ROM and comfort zone. Finally, light effleurage was applied to the entire limb and neck area, working from distal to proximal. (Total treatment time was approximately 69-70 min.)

During the final 5-6 minutes, the client was instructed in home care exercises specifically designed to lengthen the tissues associated with the $\mathrm{GH}$ joint, 
including chest muscles, rotator cuff, and shoulder, interscapular, back, cervical, and elbow and wrist muscles. These exercises included "L"-circles (with elbow bent and forearm raised to form a capital letter "L" the fingers are placed on top of the shoulder at the acromion and the elbow is moved in a circle, leading a circumduction at the GH joint), and wrist and elbow extensor exercises. These were to be repeated several times per day.

\section{Session Two (1.0 hr)}

The client returned four days later (about seven weeks following mastectomy), reporting she had practiced the home care exercises as instructed. She reported having full ROM of her arm, with no pain $(0 / 10)$ or distress on GH flexion or abduction; extension of wrist and elbow were also without pain $(0 / 10)$ or restrictions. She reported minimal residual restriction in extension only upon her customary hyperextension of elbow and wrist. On bilateral active-free testing (performed by the client), she had full ROM with no restrictions; neither the rope-like band from axilla to antecubital fossa nor the dental-floss-like structure from elbow to wrist were evident. Residual cording could be detected visually and on palpation only on hyperextension of elbow and wrist (Figure 1(c)). No signs of lymphedema were observed, nor did the client report any symptoms.

After assessment $(5 \mathrm{~min})$ and integrative lymph drainage $(5 \mathrm{~min})$, with the client in a supine position, light effleurage warm-up strokes were applied to neck, shoulder, and pectoral regions. Therapeutic massage using methods of dynamic angular petrissage was applied (total $25 \mathrm{~min}$ ) to the same areas and structures as in Session One. During the final 25 minutes, other areas of the body were treated as requested, including abdominal region, legs and lower back. The client was instructed to continue home care exercises.

\section{Three-month follow-up}

The client returned for scheduled follow-up 14.5 weeks after Session One. Cervical, GH and distal extremity ROMs were assessed, and the client was asked to report any associated pain. The client was examined and questioned for any signs or symptoms of lymphedema.

\section{RESULTS}

\section{Outcomes after Session One}

The client self-reported movement-associated pain at GH joint, elbow, and wrist as 0/10 (complete resolution; Table 2). Active-free GH ROM was improved by $30^{\circ}$ to $170^{\circ}$. Hyperemia (increased blood flow) was observed in treated areas as superficial redness. Whereas on pre-treatment palpation the cord was prominent and distinct from the other tissues, post-treatment the cord felt as part of the arm structure and was visibly reduced but not torn or ruptured (Figure 1(b)). The client reported she did not feel any pain during treatment. One day later, she called to report the axillary cording was only half as initially prominent: "The whole web or cord system seems to have relaxed to the point where I can basically move my arm how I want, with littleto-no pain." The most "annoying" pain had been at wrist and elbow "and these are where I'm feeling a massive relief." In all, the client described the improvement in her condition as $70 \%$. For the first time since detection of AWS she was able to shave her underarm area.

\section{Outcomes after Session Two}

During re-assessment with active-free functional testing of shoulder, elbow, and wrist, the cord was residually apparent in the axilla, but the client reported that she did not feel any restriction during extension or even upon hyperextension (Figure 1(c); Table 2). ROM of the GH joint was unrestricted. She self-rated her pain levels associated with movement after treatment as $0 / 10$ in GH joint, elbow, and wrist. She again reported that she did not feel any pain during treatment.

\section{Intermediate-term Outcomes}

Eight-and-a-half weeks after Session One the client called to report that the cord was now localized to just the vicinity of the scar, that movement was without pain, and emailed a photo (Figure 1(d), taken in a mirror; Table 2).

\section{Long-term Outcomes}

On scheduled three-month follow-up (14.5 weeks after Session One) and without further intervention beyond home care exercises, active-free ROM testing revealed no movement restrictions, and no palpable or visible signs of AWS (Figure 1(e); Table 2 ). The client also reported that she remained free of movement-associated pain $(0 / 10$ at $\mathrm{GH}$ joint, elbow, and wrist) and AWS restrictions or cording, and had not experienced any treatment-related pain or negative consequences following her therapy. She continued to be free of any signs or symptoms of lymphedema.

\section{DISCUSSION}

Therapeutic massage using dynamic angular petrissage is detailed in its approach, and is applied within the client's ROM and comfort zone. Indeed, 
for this client with AWS, unlike with some other standard massage and physical therapy approaches used for this condition, ${ }^{(8)}$ care was taken to ensure the cord was not ruptured as determined by lack of a sudden change in cord tension or audible popping sound. This avoids initiating a local inflammatory process or damaging lymphatic tissue which could conceivably interfere with healing and increase risk for lymphedema. ${ }^{(8)}$

Precise mechanisms of cord release achieved with this client are not clear, but can be hypothesized. The dynamic angular petrissage treatment approach specifically addresses soft tissue restrictions, and is based upon the therapist's detailed knowledge of all structures and functions involved. In this case, petrissage and non-petrissage techniques were selected and applied simultaneously with passive relaxed limb movement. The result was to passively lengthen (stretch) and shorten (relax) the contractile target tissues through their natural dynamic ranges and at the same time to actively release any functionally resistive interwoven or adhered non-contractile tissue. The highly controlled stretching/relaxation of target muscles and associated contractile soft tissues was localized to shorter and then to longer sections (segments), while carefully assessing for any pathologic resistance from non-contractile elements (e.g., fascia, tendons, ligaments, scar tissue, adhesions). Technique combinations and applied intensities (speed of movement, degree of pressure, amount of drag) were modified according to the conditions of the tissues being worked and the desired restriction release. In this way, pathologic non-contractile elements such as adhesions would have been gradually loosened. (31) Changes in tautness, texture, and attachment of the AWS cord to surrounding tissues were readily evident by palpation, so the manual pressure and manipulations may have released any adhesions associated with the cord, rendering it both less obvious and restricting of movement.

As the restricting soft tissues involving the cord were released, the anticipated pain associated with movement may have become less threatening. That is, the deleterious cycle of pain, fear of pain, and physical guarding against anticipated pain may have created tensions in the entire shoulder girdle and forearm, and thereby maintained and tightened the cord once established. Applying the massage techniques may have both directly (physically) released the involved tissues, and, by interrupting the deleterious pain cycle, facilitated an alternative proprioceptive environment that allowed (rather than forced) the tissues associated with the cord to release. In this regard, the importance of keeping the movement and pressure within the client's comfort zone may be critical to treatment success.

This report describes treatment of a client AWS as assessed, treated, and evaluated by the first author.
Every effort has been made to maintain professional objectivity in presenting the details of the case and the qualitative and quantitative outcomes. In appreciation of the relief from signs and symptoms of AWS provided to the client, she provided unsolicited interim follow-up and self-photos and gladly consented to have her case reported. We recognize, however, that some bias in the discussion of this case may have been impossible to avoid.

\section{CONCLUSION}

Axillary web syndrome is not rare, and no standard of care has yet been established. In this case, dynamic angular petrissage (with added home care exercises) resolved all of the client's signs and symptoms after two treatment sessions, without causing the client any additional discomfort. Given these results, coupled with long-term (3-month) efficacy and absence of any evident negative consequences, we suggest that dynamic angular petrissage has the potential to be of considerable use in the treatment of AWS. The first author is currently using this therapeutic technique to successfully treat other conditions in which soft tissue adhesion or contracture causes pain and restricted ROM. As it can readily be taught and applied according to a defined protocol, application in therapeutic massage practice and unbiased testing via clinical trials of efficacy are anticipated to be both feasible and valuable.

\section{ACKNOWLEDGMENTS}

We wish to thank Ms. Susan Bassonette (RMT) and Mr. Bruce McKinnon (RMT) for their encouragement during the development of this treatment approach. Mr. Thomas Klie-Cribb (RMT) contributed the concept that massage may facilitate creation of an alternative proprioceptive environment, thus interrupting the cycle of pain, fear of pain, and physical guarding. We also thank the client described in this case report for her willingness to provide contextual information and permission to use photographs (including the self-photo she had provided prior to final follow-up visit). This case report was a Silver winner in the Massage Therapy Foundation 2014 case report contest. We thank the Foundation, and particularly Dr. Niki Munk, for editorial assistance in preparing this manuscript for publication.

\section{CONFLICT OF INTEREST NOTIFICATION}

The authors have no conflict of interest regarding this work. The treatment method described is not proprietary. No outside funding sponsorship was provided. 


\section{COPYRIGHT}

Published under the CreativeCommons AttributionNonCommercial-NoDerivs 3.0 License.

\section{REFERENCES}

1. Anderson RT, Kimmick GG, McCoy TP, Hopkins J, Levine E, Miller G, et al. A randomized trial of exercise on well-being and function following breast cancer surgery: the RESTORE trial. J Cancer Surviv. 2012;6(2):172-181.

2. McNeely ML, Binkley JM, Pusic AL, Campbell KL, Gabram S, Soballe PW. A prospective model of care for breast cancer rehabilitation: postoperative and postreconstructive issues. Cancer. 2012;118(8 suppl):2226-2236.

3. Petito EL, Nazário AC, Martinelli SE, Facina G, De Gutiérrez MG. Application of a domicile-based exercise program for shoulder rehabilitation after breast cancer surgery. Rev Lat Am Enfermagem. 2012;20(1):35-43.

4. American Cancer Society. Exercises After Breast Surgery. http://www.cancer.org/cancer/breastcancer/moreinformation/ exercises-after-breast-surgery. Last Revised June 19, 2013. Accessed 1 September 2014.

5. Moskovitz AH, Anderson BO, Yeung RS, Byrd DR, Lawton TJ, Moe RE. Axillary web syndrome after axillary dissection. Am J Surg. 2001;181(5):434-439.

6. Rashtak S, Gamble GL, Gibson LE, Pittelkow MR. From furuncle to axillary web syndrome: shedding light on histopathology and pathogenesis. Dermatology. 2012;224(2):110-114.

7. O’Toole J, Miller CL, Specht MC, Skolny MN, Jammallo LS, Horick N, et al. Cording following treatment for breast cancer. Breast Cancer Res Treat. 2013;140(1):105-111. doi:10.1007/ s10549-013-2616-9

8. Yeung WM, McPhail SM, Kuys SS. A systematic review of axillary web syndrome (AWS). J Cancer Surviv. 2015;9(4): 576-598.

9. Tilley A, Thomas-MacLean R, Kwan W. Lymphatic cording or axillary web syndrome after breast cancer surgery. Can J Surg. 2009;52(4):E105-E106.

10. Leduc O, Sichere M, Moreau A, Rigolet J, Tinlot A, Darc S, et al. Axillary web syndrome: nature and localization. Lymphology. 2009;42(4):176-181.

11. Johansson K, Ingvar C, Albertsson M, Ekdahl C. Arm lymphoedema, shoulder mobility and muscle strength after breast cancer treatment? A prospective 2-year study. Adv Physiother. 2001;3(2):55-66.

12. Salmon RJ, Berry M, Hamelin JP. A novel treatment for postoperative Mondor's disease: manual axial distraction. Breast J. 2009;15(4):381-384. doi:10.1111/j.1524-4741.2009.00741.x

13. Shoham Y, Rosenberg N, Krieger Y, Silberstein E, Arnon O, Bogdanov-Berezovsky A. [Axillary web syndrome - a variant of Mondor's disease, following excision of an accessory breast] [in Hebrew]. Harefuah. 2011;150(12):893-894.

14. Leidenius M, Leppanen E, Krogerus L, von Smitten K. Motion restriction and axillary web syndrome after sentinel node biopsy and axillary clearance in breast cancer. Am J Surg. 2003; 185(2):27-30.
15. Reedijk M, Boerner S, Ghazarian D, McCready D. A case of axillary web syndrome with subcutaneous nodules following axillary surgery. Breast. 2006;15(3):410-412.

16. Alvarez-Garrido H, Garrido-Rios AA, Sanz-Munoz C, Miranda-Romero A. Mondor's disease. Clin Exp Dermatol. 2009;34(7):753-756.

17. Josenhans E. Physiotherapeutic treatment for axillary cord formation following breast cancer surgery. Pt Zeitschrift für Physiotherapeuten. 2007;59(9):868-878.

18. Lauridsen MC, Christiansen P, Hessov I. The effect of physiotherapy on shoulder function in patients surgically treated for breast cancer: a randomized study. Acta Oncol. 2005;44(5):449-457.

19. Torres Lacomba M, Mayoral Del Moral O, Coperias Zazo JL, Yuste Sánchez MJ, Ferrandez JC, Zapico Goñi A. Axillary web syndrome after axillary dissection in breast cancer: a prospective study. Breast Cancer Res Treat. 2009;117(3):625-630.

20. Yang EJ, Park W-B, Seo KS, Kim S-W, Heo C-Y, Lim J-Y. Longitudinal change of treatment-related upper limb dysfunction and its impact on late dysfunction in breast cancer survivors: a prospective cohort study. J Surg Oncol. 2010;101(1):84-91.

21. Husted MA, Haugaard K, Soerensen J, Bokmand S, Friis E, Holtveg $\mathrm{H}$, et al. Arm morbidity following sentinel lymph node biopsy or axillary lymph node dissection: a study from the Danish Breast Cancer Cooperative Group. Breast. 2008;17(2):138-147.

22. Wernicke AG, Shamis M, Sidhu KK, Turner BC, Goltser Y, $\mathrm{Khan}$ I, et al. Complication rates in patients with negative axillary nodes 10 years after local breast radiotherapy after either sentinel lymph node dissection or axillary clearance. Am J Clin Oncol. 2013;36(1):12-19.

23. Kepics JM. Physical therapy treatment of axillary web syndrome. Rehabil Oncol. 2004;22(1):21-22.

24. Severeid K, Simpson J, Templeton B, York R, Hummel-Berry $\mathrm{K}$, Leiserowitz A. Lymphatic cording among patients with breast cancer or melanoma referred to physical therapy. Rehabilitation Oncol. 2007;25(4):8-13.

25. Wyrick SL, Waltke LJ, Ng AV. Physical therapy may promote resolution of lymphatic cording in breast cancer survivors. Rehabilitation Oncol. 2006;24(1):29-34.

26. Pappo I, Wasserman I, Stahl-Kent V, Sandbank J, Halevy A. Mondor's disease of the axilla: a rare complication of sentinel node biopsy. Breast J. 2004;10(3):253-255.

27. Fourie WJ, Robb KA. Physiotherapy management of axillary web syndrome following breast cancer treatment: discussing the use of soft tissue techniques. Physiotherapy. 2009;95(4): 314-320.

28. Gagnier JJ, Kienle G, Altman DG, Moher D, Sox H, Riley DS, the CARE group. The CARE guidelines: consensus-based clinical case report guideline development. J Clin Epidemiol. 2014;67(1):46-51.

29. Munk N and Boulanger K. Adaptation of the CARE guidelines for therapeutic massage and bodywork publications: Efforts to improve the impact of case reports. Int $J$ Ther Massage Bodywork. 2014;7(3):31-40.

30. How we measure pain, discomfort and movement in a patient. Rutland, UK: Clare House Physiotherapy Ltd.; 2015. Available from: http://www.clarehousephysio.co.uk/measuring-pain-andjoint-movement.php. Accessed 17 July 172015. 
31. Rattray F, Ludwig L. Clinical Massage Therapy: Understanding, Assessing and Treating Over 70 Conditions. Elora, ON: Talus Inc.; 2000.

32. Peat M. Functional anatomy of the shoulder complex. Phys Ther. 1986;66(12):1855-1865.

33. Magee, DJ. Orthopedic Physical Assessment, Enhanced Edition, 4th edition. Edmonton: Saunders Elsevier; 2005. p.291-295.
Corresponding author: Paul A. Lewis, BA, RMT, CDT, Paul Alexander Lewis Services, Inc., 831 North Service Rd., Mississauga, ON, L4Y 1A2, Canada E-mail: plewis123@hotmail.com 